Review article

\title{
The most important message in the history of mankind
}

\author{
Piotr Skubała \\ Department of Ecology, University of Silesia, Bankowa Str. 9, 40-007 Katowice, Poland \\ E-mail address: piotr.skubala@us.edu.pl
}

\begin{abstract}
It the long history of life on the Earth five major mass extinctions were observed. Nowadays, the impact of human activities on the planet has accelerated the loss of species and ecosystems to a level comparable to a sixth mass extinction, the first driven by a living species. Surprisingly, this fact rarely reaches the public consciousness. The negative influence of human activity is observed in whole area of land ecosystems, whereas marine ecosystems are at risk of entering a phase of extinction unprecedented in human history. We have domesticated landscapes and ecosystems causing unforeseen changes in ecosystem attributes. Humanity has already overshot global biocapacity by $50 \%$ and now lives unsustainabily by depleting stocks of natural capital. Three the Earth-system processes - climate change, rate of biodiversity loss and interference with the nitrogen cycle - have already transgressed their boundaries. Human activities are of sufficient magnitude to suggest that we have triggered a new geological epoch, the Anthropocene. The "Biosphere 2" project revailed that we are not able to build and control a different system life and that we are totally dependent on the present biosphere. The experiment known in the literature as "The Tragedy of the Commons" reminds us that we need frugality and cooperation to solve environmental problems and survive.
\end{abstract}

KEY WORDS: extinction, land and marine ecosystems, loss of biodiversity, Earth-system processes, anthropocene, Biosphere 2 , Tragedy of the Commons

ARTICLE HISTORY: received 13 April 2016; accepted 7 June 2016

Probably no one has yet conducted a survey relating to the following question: What is the most important message in human history? Certainly we would get a whole range of responses. I am convinced that very few people would think of the issue which is the subject of the following article. This is probably due to the fact that this subject is not on the front pages of newspapers. It rarely gets into the public consciousness. Students indeed meet with this topic during the process of education at schools or universities, but quickly and effectively displace it from consciousness. People rarely or never discuss about it during daily meetings. Probably few of us thinking about it, while going to bed.

\section{The Earth stands on the brink of its sixth mass extinction}

The long history of the Earth was interesting and rich in various events. It has been established that life (especially multicellular animal life) has experienced five major and many minor mass extinctions (GOULD, 2004). An extinction event is a widespread and rapid decrease in the amount of life on Earth. Such biotic crisis is identified by a sharp change in the diversity and abundance of multicellular organisms. It occurs when the rate of extinction increases with respect to the rate of speciation.

The Great Oxygenation Event was probably the first major extinction event. However, since the Cambrian explosion five further major mass extinctions have significantly exceeded the background extinction rate. The "Big Five" cannot be so clearly defined, but rather appear to represent the largest (or some of the largest) of a relatively smooth continuum of extinction events (ALROY, 2008).

The first mass extinction at the end of Ordovician (443 million years ago) probably coincides with very rapid glaciation. Sea level fell by more than 
100 metres, devastating shallow marine ecosystems. Less than a million years later, there was a second wave of extinctions as ice melted, sea level rose rapidly, and oceans became oxygendepleted. Some 360 million years ago (late Devonian) a messy prolonged event was observed. Again many forms of life in shallow seas disapeared very hard. The extinction was probably due to climate change. The greatest of all, 'The Great Dying' of more than $95 \%$ of species (250 million years ago, Permian-Triassic) was strongly linked with massive volcanic eruptions in Siberia that caused, among other effects, a brief savage episode of global warming. The next mass extinction (Triassic-Jurassic, 200 million years ago) has been linked with another huge outburst of volcanism. The fifth extinction (Cretaceous-Tertiary, 65 million years ago) killed off the dinosaurs and much else. Probably an asteroid impact on Mexico did the damage (ALROY, 2008; BARNOSKY ET AL., 2011).

And now currently ongoing we observed Holocene extinction. Humans have increased the species extinction rate by as much as 1,000 times over background rates typical over the planet's history (MILLENNIUM ECOSYSTEM ASSESSMENT, 2005). We are witnessing the start of a mass extinction of species that will, if allowed to run its course, leave a deeply depaurized biosphere for at least five million years - a period twenty times longer than humans have been humans (MYERS, 2005). This specific crisis in the history of the biosphere has some very special features. Indeed, there has been nothing remotely like it in our planet's history. None of previous causes of mass extinctions has really figured in the current biological crisis. Not even climate change, which is still only in its early stages. Instead, the extinction is being driven by the actions of one species, Homo sapiens. Such a mass extinction has not occurred before. Some scientists estimate that this extinction would grow to rival the last great catastrophe of the past, when the dinosaurs and much else died out 65 million years ago, in as little as three human lifetimes (ZALASIEWICZ, 2015). Others underlined that there was only one possible exception. It occurred some 2.5 billions years ago, when a type of microbe evolved photosynthesis to spew out oxygen. A gas that would have been highly toxic to the other microbes living then, and these would have been pushed to the fringes of life on Earth - where they still remain.

What is really specific in current extinction is that the species which is the cause of the event is land-living, but has managed to become the top predator in the oceans too and has caused irreversible damage to all earth's ecosystems. It is in every sense a tragedy - but, in itself, it might be viewed as just one more episode of biological destruction in our planet's history. Recovery from such catastrophic species loss would probably take millions of years (BARNOSKY ET AL., 2011). The Earth has been here before - and will be here again, before its life is completely extinguished a billion or so years into the future. Our destructive activity is a threat to our species, not for the Earth.

Why this crucial information is not obvious or well-known for all of the world's population? Why this message does not reach humans? Paul Gilding (the veteran Australian environmentalistentrepreneur), in the book called "The Great Disruption: Why the Climate Crisis Will Bring On the End of Shopping and the Birth of a New World" wondered whether a few years from now we'll look back at the first decade of the 21st century when food prices spiked, energy prices soared, world population surged, tornados plowed through cities, floods and droughts set records, populations were displaced and governments were threatened by the confluence of it all - and ask ourselves: What were we thinking? How did we not panic when the evidence was so obvious that we'd crossed some growth/climate/natural resource/ population redlines all at once? (GILDING, 2011). For the author the only answer is denial. He argued: "When you are surrounded by something so big that requires you to change everything about the way you think and see the world, then denial is the natural response. But the longer we wait, the bigger the response required" (GILDING, 2011).

\section{Lands under the direct influence of man}

Our biosphere is sick. We have a planet that behaves like an infected organism. Each element of the biosphere is being destroyed and it's getting faster. Over the last few decades there has been no published scientific article that would deny this assertion. Let's look at our planet and the state of its ecosystems according to the recent scientific reports. At first let's consider the environmental conditions at terrestrial ecosystems.

KAREIVA ET AL. (2007) noted that as many as $83 \%$ of terrestrial ecosystems is under the direct influence of human activities. Few locations in the world remain without human influence. These areas are indicated by one of the following: human population density greater than one person/ $/ \mathrm{km}^{2}$; agricultural land use; towns or cities; access within $15 \mathrm{~km}$ of a road, river, or coastline; or nighttime light detectable by satellite. However, there really is no such thing as nature untainted by people. The impact of industry and agriculture 
is global, climate change is affecting the entire planet (Kareiva et al., 2007).

Over 14\% of Earth's land area has been designated as a natural protected area, but most of this landscape is under human influence and use. Furthermore, land set aside as wilderness areas represents only 1\% of Earth's land surface. The most common form of nature preservation is the creation of national parks, which although designated as protected often serve large populations of human visitors. One of the most popular national park is the Fuji-Hakone-Izu Park in Japan. It is visited by more than 100 million visitors annually. It includes spas, hotels, golf courses, and trams (KAREIVA ET AL., 2007). In Polish famous Tatra National Park (TNP), the pressure on nature is more-or-less the same. TNP covers the area of $0.07 \%$ of Polish territory, whereas is visited by 3 million of Polish citizens $(0.8 \%$ of the population). Do nature live on its own at such places?

\section{Life in the oceans in the phase of extinction}

Humans depend heavily on goods and services from the oceans, and these needs will likely increase with a growing human population. Meanwhile, human use has altered the oceans through direct and indirect means. Land-based activities affect the runoff of pollutants and nutrients into coastal waters and remove, alter, or destroy natural habitat. Ocean-based activities extract resources, add pollution, and change species composition. HALPERN and co-authors (2008) estimated that a large fraction $(41 \%)$ of marine ecosystems is strongly affected by multiple drivers. Large areas of high predicted impact occur in the North and Norwegian seas, South and East China seas, Eastern Caribbean, North American eastern seaboard, Mediterranean, Persian Gulf, Bering Sea, and the waters around Sri Lanka. However, large areas of relatively little human impact remain, particularly near the poles. The majority of very low impact areas (3.7\% of the oceans) occurs in the high-latitude Arctic and Antarctic poles, in areas with seasonal or permanent ice that limits human access. Unfortunately, projections of future polar ice loss suggest that the impact on these regions will increase substantially. The authors concluded that there is no area unaffected by human influence (HALPERN ET AL., 2008).

In 2011 the next report on life in oceans was released. And the conclusions were much worse. The international panel of experts on marine biology warned that marine species are at risk of entering a phase of extinction unprecedented in human history (Rogers \& LAFFOLEY, 2011). Increasing hypoxia and anoxia (absence of oxygen, known as ocean dead zones) combined with warming of the ocean and acidification are the three factors which have been present in every mass extinction event in Earth's history. The scientific panel concluded that the combination of stresses on the ocean is creating the conditions associated with every previous major extinction of species in Earth's history. And the speed and rate of degeneration in the ocean is far greater than anyone has predicted. Scientists underlined that many of the negative impacts previously identified are greater than the worst predictions. Dan Laffoley, Marine Chair of IUCN's World Commission on Protected Areas, Senior Advisor on Marine Science and Conservation for IUCN and co-author of the report, said something optimistic about this situation: "The challenges for the future of the ocean are vast, but unlike previous generations, we know what now needs to happen. The time to protect the blue heart of our planet is now, today and urgent" (ROGERS \& LAFFOLEY, 2011). Some authors argued that the protection of the ocean may be more important than protection of atmosphere or land because it stores more carbon, mediates climate variability and provides essential ecosystem services (STEFFEN ET AL., 2011).

\section{Harvesting the biosphere}

Many species have exerted enormous influence on the biosphere's character and productivity, but none has transformed the Earth in so many ways and on such a scale as Homo sapiens. There is no place on Earth that has not been altered by humans. We have domesticated landscapes and ecosystems in ways that enhance our food supplies, reduce exposure to predators and natural dangers, and promote commerce. The net benefits to humankind of domesticated nature seem to be positive. Unfortunately, we have made mistakes, causing unforeseen changes in ecosystem attributes. The Millennium Ecosystem Assessment summarized the global trends for 16 ecosystem services and reported that two-thirds of those services are currently declining (MillenNiUm ECOSYSTEM ASSESSMENT, 2005).

Humans have fundamentally modified the terrestrial landscape and marine environment in which ecosystems develop, with some $50 \%$ of the land surface being modified for agricultural (about $36 \%$ ), urban, and other human-dominated purposes (FolEY ET AL., 2011; HoOKE ET AL., 2012), whilst approximately three-quarters of the Continental shelf seabed has been trawled (ZALASIEWICZ ET AL., 
2011). More than half of the world's forests have been lost in that land conversion (KAREIVA ET AL., 2007). Homo sapiens expropriates some $25-40 \%$ of the net primary production on planet Earth (BARNOSKY ET AL., 2012; BONHOMMEAU ET AL., 2013). The global harvests of food and feed crops had doubled between 1900 and 1950, the next doubling took just 25 years and that by the year 2000, when cropland occupied about $12 \%$ of the Earth's ice-free land, the global crop harvest (dominated by cereals) was nearly eight times the value in 1900 (about 2.7 billion tonnes) and the addition of crop residues (mostly cereal straw) and forage crops would nearly triple that total (SMIL, 2013).

Humans now make up a third of land vertebrates, and the animals that we keep to eat make up most of the other two thirds. In 1900 the living mass of domesticated animals was about three times as large as that of all wild mammals but by the year 2015 the mass of domesticated ruminants (cattle, water buffaloes, sheep, goats), horses, pigs and poultry was at least 25 times larger. A percentage of mammalian zoo mass - human beings and our domesticated mammalian animals have gone from $<0.1 \% 10,000$ years ago, to $10-12 \%$ at the start of the industrial revolution to between 96$98 \%$ today. As regards wild animals, they are now less than $5 \%$ by mass and they are pushed to the edge (SMIL, 2013).

The most astonishing fact about our species is that in 2015 the anthropomass, the living weight of 7.3 billion people, was second only to the mass of domesticated cattle and that these two species, Bos taurus and Homo sapiens, are now (in terms of total mass) the biosphere's dominant vertebrates, truly the planet of cattle and people. Human beings can and will expand to fill every available ecological niche within reach, and has done so at the expense of other species (SMIL, 2013). Humans change things in other ways - they now direct the evolution of the animals that are useful to them, by breeding and by genetic engineering: again, it's a planetary novelty. The energy our species obtains from photosynthesis is not enough, and so we mine stored photosynthetic energy from the ground, as hydrocarbons, in enormous amounts, and use that to power our machines.

An ecological footprint is a measure of human impact on Earth's ecosystems. It's typically measured in area of wilderness or amount of natural capital consumed each year. A common way of estimating footprint is the area of wilderness of both land and sea needed to supply resources to a human population. The average world citizen has an eco-footprint of about 2.7 global average hectares while there are only 1.8 global hectare of bioproductive land and water per capita on earth. This means that humanity has already overshot global biocapacity by $50 \%$ and now lives unsustainabily by depleting stocks of natural capital. Actually, global growth is using about 1.5 Earths (MCLELLAN, 2014). Because we have only one planet it makes a rather significant problem. It is worth mentioning that if you cut down more trees than you grow, you run out of trees.

\section{The rate of loss of biodiversity}

Species extinction is a natural process, and would occur without human actions. However, recently biodiversity loss has accelerated massively. In modern times, global biodiversity is declining, via species extinction, at rates that are orders of magnitude higher than might be expected from the fossil record. Species are becoming extinct at a rate that has not been seen since the last global mass-extinction event (MACE ET AL. 2005). Today, the rate of extinction of species is estimated to be at least 100 times more than what could be considered natural (MACE ET AL., 2005). Some authors recognize that biodiversity loss is now at 1000x background levels (PIMM ET AL., 2014). Some authors estimated that within severaldecades about $50 \%$ of plant and animal species will disappear (CADOTTE ET AL., 2008). The Living Planet Index (LPI) is a measure of the state of the world's biological diversity based on population trends of vertebrate species from terrestrial, freshwater and marine habitats. The LPI has been adopted by the Convention of Biological Diversity (CBD) as an indicator of progress towards its 2011-2020 target to take effective and urgent action to halt the loss of biodiversity. The global LPI as presented in the Living Planet Report 2014 shows that a subset of 10,380 populations of 3,038 species has declined by $52 \%$ in abundance between 1970 and 2010 (MCLELLAN, 2014).

The existence value of a species is essentially unmeasurable. Further, the effects of losing even one species from an ecosystem are difficult to predict. The magnitude of effects on ecosystem functions increases in a non-linear manner as ever more biodiversity is lost, in part because the majority of species depend on symbioses with other species. Sceptics say that extinction is an inevitable consequence of evolution. However, nowadays it is not asteroids, volcanoes or methane (as in the previous extinctions) the decisive reason of extinction. The human activity is the only reason of such high rate of species extinction. Ecologist Robert D. Holt (Department of Biology, University of Florida) when asked by Nature about 
the important task in his field responded: „A key task will be to predict and mitigate this loss of biodiversity and the degradation of ecosystem function" (2020 VISIONS).

\section{Planetary boundaries}

It would be interesting to know the most important environmental factors for the functioning of the biosphere and identify the boundary for each of these processes. Do we cross a boundary for some of these processes? In 2009 Johan Rockström from Stockholm Resilience Center and co-authors define a number of boundary conditions in the earth system that could, if crossed, result in a major disruption in (parts of) the system and a transition to a different state. Scientists fund nine such processes, namely: climate change; biodiversity loss; the nitrogen cycle; the phosphorus cycle; stratospheric ozone depletion; ocean acidification; global freshwater use; land use change; atmospheric aerosol loading; and chemical pollution (ROCKSTRÖM ET AL., 2009).

An important insight of their assessment is that three the Earth-system processes - climate change, rate of biodiversity loss and interference with the nitrogen cycle - have already transgressed their boundaries. Regarding climate change, we have reached atmospheric carbon dioxide concentrations of $390 \mathrm{ppm}$ (compared to $280 \mathrm{ppm}$ in preindustrial times), whereas the threshold value would lie at $350 \mathrm{ppm}$. Regarding biodiversity, the current extinction rate is over 100 extinct species per million species per year, while the suggested threshold would be 10 extinctions. As for the nitrogen cycle, humans remove today about 121 million tons nitrogen per year from the atmosphere, while a safe rate would be, according to the planetary boundary concept, a maximum of 35 million tons. In these three areas, therefore, humankind has pushed the Earth system past tipping points into a new and unknown world (ROCKSTRÖM ET AL., 2009).

\section{The anthropocene biosphere}

The modern biosphere is unique in that much of the animal and plant variation, and ecosystem structure, is shaped by one species. Human activities have reached a level that could damage the systems that keep Earth in the desirable Holocene state. For the last 10,000 years, humans have been living in the Holocene epoch. This stability allowed humans to develop agriculture and form settled communities, culminating in the complex societies of modern times. The scale and speed of change has led to the proposal that we are moving into a new epoch, termed the Anthropocene, or literally, the 'Age of Man' (CRUTZEn, 2002). The term 'Anthropocene' was first used by Eugene Stoermer, and subsequently popularized by the atmospheric chemist and Nobel Prize laureate Paul Crutzen (CRUTZEN, 2002). Crutzen dates the beginning of the Anthropocene to the late $18^{\text {th }}$ century when atmospheric concentrations of carbon dioxide and methane began to rise significantly.

Authors characterized the anthropocene by the following features: (1) global homogenisation of flora and fauna; (2) a single species (Homo sapiens) commandeering $25-40 \%$ of net primary production and also mining fossil net primary production (fossil fuels) to break through the photosynthetic energy barrier; (3) human-directed evolution of other species; and (4) increasing interaction of the biosphere with the technosphere (WILLIAMS ET AL., 2015).

\section{The real message from Biosphere 2}

The destabilization of key planetary systems may have catastrophic consequences for humanity. Do we take appropriate steps? Will we be able to take suitable steps on time? Paul Gilding, the author of the inspiring book „The Great Disruption: Why the Climate Crisis Will Bring On the End of Shopping and the Birth of a New World" argued: "We either allow collapse to overtake us or develop a new sustainable economic model. We will choose the latter. We may be slow, but we're not stupid" (GILDING, 2011).

Many of us have unshakable faith in the power of the human mind, the belief that science and technology will find the right solution. A manifestation of this thinking is an attempt to build a second biosphere. Between 1987 and 1991 an Earth systems science research facility was constructed. It was named "Biosphere 2 " because it was meant to be the second fully self-sufficient biosphere, after the Earth itself. Biosphere 2 is a futuristic glass and steel greenhouse located in Arizona's Sonoran desert. It is a 1.27hectare structure originally built to be an artificial, almost completely sealed off from atmospheric or other material exchange with the outside world. It remains the largest closed system ever created. Its mission is to serve as a center for research, outreach, teaching, and lifelong learning about Earth, its living systems, and its place in the universe. Biosphere 2 was originally meant to explore the web of interactions within life systems in a structure with five areas based on biomes, and an agricultural area and human 
living and working space to study the interactions between humans, farming, and technology with the rest of nature. Nearly 4000 introduced species of plants and animals were placed in a setting of tropical rainforest, marsh, desert, savannah, streams, agricultural area, and even a miniature ocean complete with coral reef. Biosphere 2 receives energy as sunlight and as electricity that driver a vast "technosphere" to keep the environmental systems within boundaries suitable for life (AVISE, 1994).

Biosphere 2 was only used twice for its original intended purposes as a closed-system experiment: once from 1991 to 1993, and the second time from March to September 1994. Both attempts, though heavily publicized, ran into problems including low amounts of food and oxygen, die-offs of many animal and plant species, squabbling among the resident scientists and management issues (COHEN \& TILMAN, 1996). During the two years of living (1991-93) in the Biosphere 2 the eight Biospherans became aware of their intimate connections with, and completely dependence upon, the fragile ecosystems within Biosphere 2. Jane Poynter, a Biosphere 2 crewmember, underline one important thing from the period of two years in the other world: "At that moment I became part of that biosphere. And I don't mean that in an abstract sense; I mean it rather literally. When I breathed out, my $\mathrm{CO}_{2} \mathrm{fed}$ the sweet potates that I was growing" (Jane Poynter).

John C. Avise, the author of the editoral in Conservation Biology on the Biosphere 2, underlined that surely the Biospherans would never have torelated in their small household the kinds of practices that are so widespread in our broader world, e.g. massive deforestation, water and atmospheric pollution, the dumping of toxic chemicals, or overexploitation of renewable and nonrenewable resources (AVISE, 1994). The cost of the Biosphere 2 for eight Biospherans over two years was about $\$ 150$ million, or 9 million per person per year. These services are provided to the rest of us more-or-less cost-free by natural processes. But if we were being charge, the total invoice for all Earthospherians would come to an astronomical three quintillion dollars for the current generation alone (AvISE, 1994). The two years experiment in Biosphere 2 was finished in 1993. The eight Biospherans returned to our world. Unlike the inhabitants of Biosphere 2, we have no outside living world. We can dream about colonizing other planets, but the harsh reality is that we have only this planet to live.

\section{The Tragedy of the Commons}

What do we need to survive and not to destroy the planet? Wishing to visualize what we really need I usually recall the famous scientific experiment from 1968 described by Garrett Hardin (American biologist) in the journal Science. In 1968, the author explored certain social dilemma in his article "The Tragedy of the Commons". Hardin focused on human population growth, the use of the Earth's natural resources, and the welfare state. Hardin argued that if individuals relied on themselves alone, and not on the relationship of society and man, then the number of children had by each family would not be of public concern. He also pointed out the problem of individuals acting in rational self-interest by claiming that if all members in a group used common resources for their own gain and with no regard for others, all resources would still eventually be depleted (HARDIN, 1968).

I invite usually three persons to this experiment. Before them I set a dish with nine walnuts. They symbolize environmental resources. I instruct participants that on my signal, they will be able to use resources. The amount of resources they will take, I leave their decision. I announce only that if they leave any resources, I will be responsible for adding the same number of walnuts. In this way I will simulate the regeneration of resources by ecosystems. The result of the experiment in the first round is usually the same. All nuts disappeared. The resources are finished. The ecosystems stopped to run their services. Usually in the second or third round I encouraged participants to take the agreement that they will take the same or a similar number of resources, leaving a number of them. As a result, the number of resources is not reduced and begins to grow. Moreover, in following rounds, the participants could benefit from a little more resources.

The experiment clearly shows that in order to survive and not destroy the natural resources on which we are closely dependent, we require first of all - frugality. We live on a planet with limited resources and there is no other way to live for us. Unfortunately, frugality is not enough. It is necessary to learn to cooperate and trust in other people. It is not easy, but there is no other way. Many human civilizations have collapsed in the past, usually due to complex combinations of environmental, social and economic factors (BUTZER \& ENDFIELD, 2012). We owe it to future generations to not repeat the mistakes made in the past, and to invest in the future of our planet now, rather than pay a higher price later. 
Zygmunt Bauman, the author of the preface to the Polish translation of the book entitled "Climate Wars: What People Will Be Killed For in the 21st Century" noted: "It's high time to awake out of collective coma" (BAUMAN, 2010).

Some 1,700 of the world's leading scientists, including the majority of Nobel laureates in the sciences, issued the appeal entitled "World Scientists' Warning to Humanity" in November 1992. This statement begins: "Human beings and the natural world are on a collision course" (1992 WORLD SCIENTISTS' WARNING TO HUMANITY). After nearly 25 years, the situation has not been improved. On the contrary, it is more dangerous. As the scientists and academics from different disciplines (not only natural sciences) we should be able to make the alarming message on biodiversity depletion sound to the broad circles of society. But an even greater challenge is do everything to answer the question: how to make the dramatic facts appealing to the public consciousness?

\section{References}

1992 World Scientists' Warning to Humanity. http://www.ucsusa.org/about/1992-world-scientists.html \#.V1MVmb7feMk (accessed on 2 April 2016)

2020 Visions. Nature (7 January 2010), 463(7): 26-32.

Alroy J. 2008. Dynamics of origination and extinction in the marine fossil record. P. Natl. Acad. Sci. USA, 105(1): 1153611542.

Avise J.C. 1994. The Real Message from Biosphere 2. Conserv. Biol., 8: 327-329.

Barnosky A.D., Matzke N., Tomiya S., Wogan G.O.U., Swartz B., Quental T.B., Marshall C., McGuire J.L., Lindsey E.L., Maguire K.C., Mersey B., Ferrer E.A. 2011. Has the Earth/'s sixth mass extinction already arrived? Nature, 471(7336): 51-57.

Barnosky A.D., Hadly E.A., Bascompte J., Berlow E. L., Brown J. H., Fortelius M., Getz W. M., Harte J., Hastings A., Marquet P. A., Martinez N. D., Mooers A., Roopnarine P., Vermeij G., Williams J. W., Gillespie R., Kitzes J., Marshall C., Matzke N., Mindell D. P., Revilla E., Smith A. B. 2012. Approaching a state-shift in the biosphere. Nature 486: 52-56.

Bauman Z. 2010. Przedmowa. Panika wśród pasożytów, czyli komu bije dzwon. [in:] Welzer H. Wojny klimatyczne. Za co będziemy zabijać w XXI wieku? Wyd. Krytyki Politycznej, Warszawa: 5-13.

Bonhommeau S., Dubroca L., Le Pape O., Barde J., Kaplan D.M., Chassot E., Nieblas A.-E., Kaplan D.M. 2013. Eating up the world's food web and the human trophic level. P. Natl. Acad. Sci. USA, 110: 20617-20620.

Butzer K.W., Endfield G.H. 2012. Critical perspectives on historical collapse. P. Natl. Acad. Sci. USA, 109(10): 3628-3631.

Cadotte M.W., Cardinale B. J., Oakley T.H. 2008. Evolutionary history and the effect of biodiversity on plant productivity. P. Natl. Acad. Sci. USA, 105(44): 17012-17017.

Cohen J.E., Tilman D. 1996. Biosphere 2 and Biodiversity. The Lessons So Far. Science, 274 (5290): 1150-1151.

Crutzen P.J. 2002. Geology of mankind. Nature, 415: 23.

Foley J.A., Ramankutty N., Brauman K.A. Cassidy E.S., Gerber J.S., Johnston J.S., Mueller N.D., O'Connell C., Ray D.K., West P.C., Balzer C., Bennett E.M., Carpenter S.R., Hill J.,
Monfreda C., Polasky S., Rockström J., Sheehan J., Siebert S., Tilman D., Zaks D.P. 2011. Solutions for a cultivated planet. Nature, 478: 337-342.

Gilding P. 2011. The Great Disruption: Why the Climate Crisis Will Bring On the End of Shopping and the Birth of a New World. Bloomsbury Press, New York.

Gould, S. J. 2004. The Evolution of Life on Earth, Dinosaurs and Other Monsters. Sci. Am. Special, 14: 95-100.

Halpern B.S., Walbridge S., Selkoe K.A., Kappel C.V., Micheli F., D’Agrosa C., Bruno J.F., Kasey K.S., Ebert C., Fox H.E., Fujita R., Heinemann D., Lenihan H.S., Madin E.M., Perry M.T., Selig E.R., Spalding M., Steneck R., Watson R. 2008. A Global Map of Human Impact on Marine Ecosystems. Science, 319: 948-952.

Hardin G. 1968. The Tragedy of the Commons. Science, 162: 1243-1248.

Hooke R.Le., Martin-Duque J.F., Pedraza J. 2012. Land transformation by humans, a review. GSA Today, 22(12): 4-10.

Jane Poynter. Life in Biosphere 2. [in:] TED: Ideas worth spreading. Talks [on-line]. http://www.ted.com/talks/jane_ poynter_life_in_biosphere_2.html (accessed on 2 April 2016).

Kareiva P., Watts S., McDonald R., Boucher T. 2007. Domesticated Nature: Shaping Landscapes and Ecosystems for Human Welfare. Science, 316: 1866-1869.

Mace G., Masundire H., Baillie J., Ricketts T., Brooks T., et al. 2005. Biodiversity. [in:] Hassan R., Scholes R., Ash N. (eds). Ecosystems and human well-being: Current state and trends: Findings of the Condition and Trends Working Group. Washington (D. C.), Island Press: 77-122.

McLellan R. (editor in chief) 2014. Living Planet Report 2014, World Wildlife Fund. http://wwf.panda.org/about_ our_earth/all_publications/living_planet_report/ (accessed on 2 April 2016).

Millennium Ecosystem Assessment 2005. Ecosystems and Human Well-being: Synthesis. Island Press, Washington, DC.

Myers N. 2005. The Biotic Crisis: Mass Extinction of Species and Disruption of Future Evolution. UNU/IAS, Working Paper, 102, pp. 24. http://www.ias.unu.edu/resource_ centre/UNU-IAS\%20Working\%20Paper\%20No.102.pdf; (accessed on 2 April 2016).

Pimm S.L., Jenkins C.N., Abell R., Brooks T.M., Gittleman J.L., Joppa L.N., Raven P.H., Roberts C.M., Sexton J. O. 2014. The Biodiversity of Species and Their Rates of Extinction, Distribution, and Production. Science, 344: 987-998.

Rockstrom J., Steffen W., Noone K., Persson Å., Chapin F.S. III, Lambin E., Lenton T.M., Scheffer M., Folke C., Schellnhuber H.J., Nykvist B., de Wit C.A., Hughes T., van der Leeuw S., Rodhe H., Sörlin S., Snyder P.K., Costanza R., Svedin U., Falkenmark M., Karlberg L., Corell R.W., Fabry V.J., Hansen J., Walker B., Liverman D., Richardson K., Crutzen P., Foley J. 2009. Planetary Boundaries: Exploring the Safe Operating Space for Humanity. Ecology Soc., 14(2): 32 [online] URL: http://www.ecologyandsociety.org/vol14/iss2/art32/

Rogers A.D., Laffoley D.d'A. 2011. International Earth system expert workshop on ocean stresses and impacts. Summary report. IPSO Oxford, pp. 18.

Smil V. 2013. Harvesting the Biosphere: How Much We Have Taken from Nature. The MIT Press, Cambridge, MA.

Steffen W., Persson Å., Deutsch L., Zalasiewicz J., Williams M., Richardson K., Crumley C., Crutzen P., Folke C., Gordon L., Molina M., Ramanathan V., Rockström J., Scheffer M., Schellnhuber H.J., Svedin U. 2011. The Anthropocene: From Global Change to Planetary Stewardship. Ambio, 40(7): 739-761.

Williams M., Zalasiewicz J., Haff P.K., Schwägerl C., Barnosky A.D., Ellis E.C. 2015. The Anthropocene biosphere. The Anthropocene Review, 1-24. 
Zalasiewicz J. 2015. The Earth stands on the brink of its sixth mass extinction and the fault is ours. The Guardian, Sunday 21 June 2015 http://www.theguardian.com/ environment/2015/jun/21/mass-extinction-sciencewarning; (accessed on 2 April 2016)

Zalasiewicz J.A., Williams M., Fortey R. et al. 2011. Stratigraphy of the Anthropocene. Philos. T. R. Soc., A369: 1036-1055. 